\title{
Sclerotiamide: The First Non-Peptide-Based Natural Product Activator of Bacterial Caseinolytic Protease $\mathbf{P}$
}

\author{
Nathan P. Lavey ${ }^{\dagger, \ddagger, \perp}$, Jesse A. Coker ${ }^{\dagger, \ddagger, \perp}$, Eliza A. Ruben ${ }^{\ddagger, \S}$, and Adam S. Duerfeldt ${ }^{\dagger, \ddagger,{ }^{*}}$ \\ †Institute for Natural Products Applications and Research Technologies, University of Oklahoma, \\ 101 Stephenson Parkway, Norman, Oklahoma 73019, United States \\ ‡Department of Chemistry \& Biochemistry, Stephenson Life Sciences Research Center, \\ University of Oklahoma, 101 Stephenson Parkway, Norman, Oklahoma 73019, United States \\ \$Protein Production Core, University of Oklahoma COBRE in Structural Biology, Norman, \\ Oklahoma 73019, United States
}

\begin{abstract}
Caseinolytic protease $\mathrm{P}(\mathrm{ClpP})$ maintains essential roles in bacterial homeostasis. As such, both the inhibition and activation of this enzyme result in bactericidal activity, making $\mathrm{ClpP}$ a promising target for antibacterial drug development. Herein, we report the results of a fluorescence-based screen of $\sim 450$ structurally diverse fungal and bacterial secondary metabolites. Sclerotiamide (1), a paraherquamide-related indolinone, was identified as the first non-peptidebased natural product activator of ClpP. Structure-activity relationships arising from the initial screen, preliminary biochemical evaluation of $\mathbf{1}$, and rationale for the exploitation of this chemotype to develop novel ClpP activators are presented.
\end{abstract}

\section{Graphical abstract}

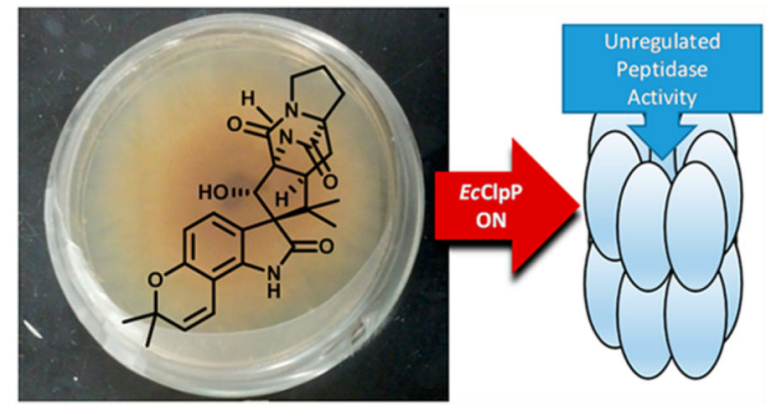

*Corresponding Author. Phone: (405) 325-2232. Fax: (405) 325-61111. adam.duerfeldt@ ou.edu.

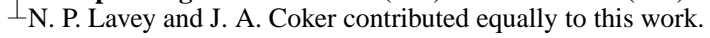

ASSOCIATED CONTENT

Supporting Information

The Supporting Information is available free of charge on the ACS Publications website at DOI: 10.1021/acs.jnatprod.5b01091.

Structures of enopeptin A and ACP5, B-score analysis of initial screen, ACP5 SDS-PAGE analysis, ADEP1 degradation curves (PDF)

The authors declare no competing financial interest. 
Despite the effectiveness of modern day antimicrobials, the ever-increasing number of multidrug-resistant pathogens urgently requires the development of alternative treatment strategies. ${ }^{1-3}$ Of particular importance is the development of therapeutics that operate through clinically unexploited mechanisms of action. ${ }^{2,4}$ Such therapies present new challenges to bacteria that require the evolution of new resistance regimes and thus lengthen the potential duration of therapeutic efficacy. One approach that deviates definitively from the status quo of traditional antibiotics is to develop compounds capable of imparting bactericidal activity via an activation mechanism, rather than an inhibitory one. Traditional antibiotics shut down or inhibit essential cellular processes (cell wall construction, protein synthesis, replication, etc.) and thus, generally rely upon a normal bacterial growth phase and/or an active cellular target. This dependency of antibiotics on microbial cooperativity often renders dormant persister cells and biofilms unresponsive to inhibitory therapeutics. ${ }^{5}$ Differentiated therapies that operate through the activation of cellular processes would provide a clinically unexploited approach, potentially independent of growth mode or target activity, and would therefore fill a prevalent void in the current antimicrobial arsenal.

One target, which produces bactericidal activity upon activation, is caseinolytic protease $\mathrm{P}$ $(\mathrm{ClpP})$. ClpP is a cylindrical serine protease composed of two stacked heptameric rings, which form a tetradecameric complex that encompasses a large proteolytic core. ${ }^{6-12}$ The primary physiological role of the $\mathrm{ClpP}$ system is to maintain homeostasis through the controlled degradation of defective and obsolete intracellular polypeptides. ${ }^{13-16}$ Under normal physiological conditions, ClpP proteolytic activity is highly regulated through interactions with ATP-dependent AAA+ co-chaperones ${ }^{17-19}$ (e.g., ClpA and ClpX), which are responsible for the denaturation, delivery, and translocation of substrates into the proteolytic core of ClpP. ${ }^{12,20-24}$ In the absence of ATP or co-chaperones, ClpP activity is limited to the degradation of small peptides ( $<6$ amino acids). ${ }^{25,26}$ Natural product or smallmolecule chemoactivation of $\mathrm{ClpP}$, however, triggers unregulated proteolysis of large polypeptides and unstructured proteins. ${ }^{27-29}$ This indiscriminant degradation results in bacterial self-digestion and eventual cellular death, including microbes in dormant or biofilm phases. ${ }^{30,31}$ Thus, activation of ClpP is an attractive therapeutic strategy worthy of detailed interrogation and medicinal chemistry efforts.

To date, the acyldepsipeptides (ADEPs, Figure 1) represent the only natural product class identified to activate ClpP. ${ }^{32,33}$ While elegant structure-activity relationship (SAR) studies and biochemical analyses have structurally and mechanistically characterized ADEP activation of ClpP and provided extremely potent derivatives, ${ }^{25,31,34-37}$ the utility of this natural product family has been limited. Much of this limitation arises from lack of activity against Gram-negative pathogens and the susceptibility of ADEPs to active efflux. ${ }^{27}$ Structural alteration of ADEPs to address these detriments has been relatively unsuccessful thus far, in part because the $N$-acylated phenylalanine pharmacophore ${ }^{38}$ is the recognized motif for efflux pumps. ${ }^{39}$ Efforts to diversify the arsenal of ClpP-activating molecules through screening or structure-based approaches have been extremely limited. In fact, other than the ADEP natural products and related congeners, only four chemically distinct smallmolecule activators have been discovered, all of which were identified within a single screen of a commercially available library. ${ }^{40,41}$ In order to allow for the continued exploration of ClpP activation as a differentiated antibacterial strategy, chemically distinct activators are 
needed. Identification of structurally divergent activating molecules would expand the chemical space upon which SAR studies can be executed and potentially provide scaffolds amenable to development as broad-spectrum antibiotics.

To this end, we screened a focused but structurally diverse subset of fungal and bacterial secondary metabolites, housed within the Institute for Natural Products Applications and Research Technologies (INPART) at the University of Oklahoma. The complete library has been established by the Cichewicz Laboratory over nearly a decade and comprises $\sim 450$ pure metabolites and $>20000$ extracts isolated from fungal and bacterial organisms collected within the United States. ${ }^{42}$ This continually growing collection includes a rich source of structural diversity (depsipeptides, alkaloids, carbocycles, terpenes, polyketides, nonribosomal peptides, etc.) and has provided leads in a number of targeted phenotypic screens and functional assays. ${ }^{43-46}$ Thus, we believed this library represented a promising untapped source to screen for novel natural product ClpP activators.

For the initial screen, a fluorescence-based protease assay that utilizes a commercially available internally quenched fluorogenic ClpP substrate, FITC- $\beta$-casein, was employed. ${ }^{41}$ We commenced our screening campaign with only the pure metabolite portion of the available natural product library, and thus $\sim 450$ natural products were screened at a single concentration $(50 \mu \mathrm{M})$ for the activation of recombinant Escherichia coli $\mathrm{ClpP}(E c \mathrm{ClpP})$. Enopeptin $\mathrm{A}^{33,47}(25 \mu \mathrm{M})$ and $\mathrm{ACP} 5^{41}(50 \mu \mathrm{M})$, a natural ADEP analogue and a small molecule, respectively, were implemented as positive controls. In the presence of an activating molecule, ClpP-mediated cleavage of FITC- $\beta$-casein relieves internal quenching of the substrate and yields a fluorescent output of protease activity that can be quantified with a fluorimeter (excitation/emission: 485/538 nm). In the absence of an activating molecule, $\mathrm{ClpP}$ is unable to proteolytically cleave FITC- $\beta$-casein and fluorescence remains quenched.

As shown in Figure 2A, a threshold of 22500 raw relative fluorescent units (RFUs) was set, and any compound exhibiting an end-point fluorescence greater than this threshold was analyzed further. In total, 11 hits were identified, two of which were the positive controls, enopeptin A (A, Figure 2A) ${ }^{33,47}$ and ACP5 (B, Figure 2A). ${ }^{41}$ The remaining nine hits were resubjected to the assay conditions to confirm the observed activity. All nine demonstrated reproducibility, which provided a respectable initial hit rate of 3.6\%. However, when the raw screening data were replotted using the B-score algorithm, ${ }^{48,49}$ only a single true hit provided a score above three standard deviations from the mean of the general sample population (Figure S2). Thus, to eliminate false positives and confirm the B-score analysis, the original hits were evaluated for intrinsic fluorescence, which disqualified eight of the nine hits (Figure 2B). To measure intrinsic fluorescence, $538 \mathrm{~nm}$ emission for each compound $(50 \mu \mathrm{M})$ in assay buffer was measured following $485 \mathrm{~nm}$ excitation. To ensure the only remaining hit was not inducing substrate degradation through inherent proteolytic activity, compound $1(50 \mu \mathrm{M})$ was incubated with FITC- $\beta$-casein $(1.92 \mu \mathrm{M})$ in assay buffer. Fluorescence readings were taken, and no significant time-dependent inherent proteolytic activity was observed. As such, sclerotiamide (1, Figure $2 \mathrm{~B}),{ }^{50}$ a paraherquamide-related indolinone natural product, was the only hit to pass both validation filters and B-score analysis and was evaluated further. 
Sclerotiamide was subjected to dose-dependent peptide (Abz-DFAPKMALVPYNO2 $)^{21,38}$ and protein (FITC- $\beta$-casein) degradation analysis. As shown in Figure 3 and Table 1, the potency of $\mathbf{1}$ in the decapeptide degradation assay is similar to that of ACP5 and exhibits an apparent activation constant $\left(K_{\text {app }}\right.$ ) of $39.6 \pm 4.9 \mu \mathrm{M}$. In the FITC- $\beta$-casein degradation assay, however, ACP5 maintains the same level of potency, whereas 1 exhibits a $K_{\text {app }}$ of 87.5 $\pm 5.0 \mu \mathrm{M}, \mathrm{a} \sim 2$.2-fold decrease in activity. It is worth noting that the consistent potency of ACP5 in these two assays differs from the trend observed for 1 and ADEP1, which also shows an increase ( $\sim 10$-fold) in $K_{\text {app }}$ from decapeptide to FITC- $\beta$-casein degradation (Table 1). This unique substrate-independent activity exhibited by ACP5 may represent a useful observation in regard to a hypothesis set forth by Houry and colleagues that ACP analogues may interact with more than one binding pocket on $E c C l p P .{ }^{41}$ Additionally, this may suggest that ACP5 and related analogues induce an alternative activation state of EcClpP, which is less sensitive to the size and/or shape of substrates. In agreement with both ADEP1 and ACP5, Hill plot analysis of $\mathbf{1}$ demonstrates modest positive cooperativity for ClpP binding (Hill coefficient $>1.0$ ). Although the potency is modest, especially in comparison to ADEP1, sclerotiamide is the first non-peptide-based natural product ClpP activator discovered and thus provides unique chemical space to evaluate for SAR studies. As a member of the paraherquamide family, 1 possesses an interesting three-dimensional bicyclo[2.2.2]-diazaoctane motif that has garnered significant attention from the synthetic community 51,52 and has recently been reported in closely related compounds that exhibit a range of biological activities. 53,54

Further validation of EcClpP activation by 1 was confirmed by SDS-PAGE analysis (Figure 4), which demonstrates time-dependent activation of EcClpP, resulting in subsequent degradation of unlabeled $\beta$-casein. The inability of $\mathbf{1}$ to completely degrade the substrate has been noted in other ClpP-activating scaffolds with similar potency. ${ }^{41}$ Interestingly, when $\mathbf{1}$ was evaluated for its propensity to activate Bacillus subtilis $\mathrm{ClpP}$ (BsClpP), the homologue typically utilized to evaluate the activity of ADEP analogues, no significant activation was observed (Figure 4). This lack of BsClpP activation was noted in both the SDS-PAGE analysis and fluorescence-based degradation assays. Surprisingly, similar homologue selective activation was noted with ACP5, albeit at a lower concentration ( $25 \mu \mathrm{M})$ (Figure S3). To the best of our knowledge, this observation provides the first report of ClpP activators that demonstrate noticeable profiles of selectivity between bacterial homologues, and we are currently probing the utility of this observation.

Upon reinvestigation of the screened compound set, we noted that six additional members of this family were included within the screen (2-7, Figure 5A). Interestingly, however, all six of these analogues fail to elicit $E c C l p P$ (Figure $5 \mathrm{~B}$ ) or $B s C l p P$ activation to any significant extent. Most notable from this group is notoamide B (2), ${ }^{55}$ which lacks only the C-10 aoriented secondary hydroxy group. This lack of activity by $\mathbf{2}$ identifies the C-10 a-hydroxy motif as a necessary fixture in this natural product family for $\mathrm{ClpP}$ activation. In addition, the three-dimensional character imparted by the spiroindolinone moiety seems to be important, as all other congeners exhibit a fused architecture and thus an altered geometry that fails to activate EcClpP. 
Indicative of its relatively modest $K_{\text {app }}$, concentrations up to $100 \mu \mathrm{M}$ of 1 failed to inhibit the growth of efflux pump deficient Escherichia coli M5418 ( $\triangle$ acrB, $\triangle a c r D, \triangle a c r E F:: s p c$ $\Delta$ emrB $\Delta$ emr $Y \Delta$ entS::cam $\triangle m a c B \Delta m d t C \Delta m d t F)^{56}$ and Pseudomonas aeruginosa

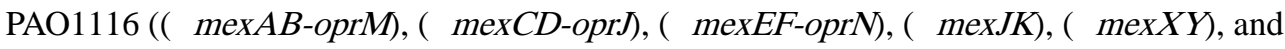
$(\triangle t r i A B C)) .{ }^{57}$ These results suggest that although $\mathbf{1}$ is capable of activating recombinant $E c \mathrm{ClpP}$, improvement of potency is required for cellular target engagement and efficacy. Molecular dissection to identify the pharmacophore for this class of ClpP-activating natural products and X-ray cocrystallization studies are currently ongoing in our laboratory. Results from these studies will be communicated in due course and will contribute to structureguided approaches aimed at improving upon the ClpP activation potency of this chemotype. Furthermore, the process outlined here will be expanded upon to enable the screening of natural product extracts, allowing for the interrogation of much larger chemical diversity.

\section{EXPERIMENTAL SECTION}

\section{General Experimental Procedures}

Positive controls were purchased from commercial sources and include enopeptin A (Santa Cruz Biotechnology, \#sc-397311A), ADEP1 (Cayman Chemical, \#15305), and ACP5 (Chembridge \#5107473). ClpP substrates were purchased from commercial vendors and include FITC- $\beta$-casein (Sigma-Aldrich, C3777, 20-50 $\mu$ g FITC per mg solid) and AbzDFAPKMALVPY ${ }^{\mathrm{NO} 2}$ (Biomatik). Fluorescence readings were recorded on an i-TECAN Infinite M200 plate reader. Gel images were acquired on a Bio-Rad ChemiDoc MP CCD imaging system. All data analyses were performed with GraphPad Prism.

\section{Protein Purification}

Two different $E$. coli cell strains were used for overexpression. EcClpP was overexpressed in BLR (DE3) from Novagen and BsClpP in BL21 (DE3) from New England Biolabs. Overexpression and purification conditions for both proteins were similar. Cell strains transformed with the relevant plasmids were grown at $37^{\circ} \mathrm{C}$ to an $\mathrm{OD}_{600}$ of 0.7 followed by induction with $1 \mathrm{mM}$ isopropyl $\beta$-D-thiogalactopyranoside and overnight overexpression at $25^{\circ} \mathrm{C}$. Cell pellets were resuspended in $20 \mathrm{mM}$ Tris and $150 \mathrm{mM} \mathrm{NaCl}(\mathrm{pH} 8.0)$ and lysed using an Avestin C3 Emulsiflex. Lysates were clarified by centrifugation at $12000 \mathrm{rpm}$ for 30 min and incubated with Ni-NTA (Qiagen) resin pre-equilibrated with $20 \mathrm{mM}$ Tris and $150 \mathrm{mM} \mathrm{NaCl}(\mathrm{pH}$ 8.0). Protein was eluted from Ni-NTA resin with $20 \mathrm{mM}$ Tris, $150 \mathrm{mM}$ $\mathrm{NaCl}$, and $500 \mathrm{mM}$ imidazole (pH 8.0) and concentrated. Gel filtration, using a Superdex 200 Increase size exclusion column (GE Healthcare), was used as a final purification step for both proteins. Gel filtration buffer conditions were $25 \mathrm{mM}$ Tris, $100 \mathrm{mM} \mathrm{KCl}$, and $10 \%$ glycerol (pH 7.5) ${ }^{58}$ for EcClpP and $25 \mathrm{mM}$ HEPES, $100 \mathrm{mM} \mathrm{KCl}, 20 \mathrm{mM} \mathrm{MgCl}_{2}, 1 \mathrm{mM}$ EDTA, and $10 \%$ glycerol $\left(\mathrm{pH} \mathrm{7.6)}{ }^{19}\right.$ for $B$ s ClpP. Protein concentrations were determined using the calculated molar extinction coefficient in $6 \mathrm{M}$ guanidinium hydrochloride. ${ }^{59}$

\section{FITC-Casein Screening Assay}

A $300 \mathrm{nM}$ tetradecameric $E c \mathrm{ClpP}$ in buffer A ( $25 \mathrm{mM}$ Tris- $\mathrm{HCl}, \mathrm{pH} 7.5$, and $100 \mathrm{mM} \mathrm{KCl})$ was incubated with compounds $(50 \mu \mathrm{M})$ at $37{ }^{\circ} \mathrm{C}$ for $15 \mathrm{~min}$ in flat bottom, nonbinding, nonsterile, white polystyrene 96-well plates (Corning 3990). After the preincubation period, 
$1 \mu \mathrm{L}$ of a $192 \mu \mathrm{M}$ FITC- $\beta$-casein solution in buffer A was added to each assay well to give a final assay concentration of $1.92 \mu \mathrm{M}$ FITC- $\beta$-casein and final assay volume of $100 \mu \mathrm{L}$. Assay plates were incubated at $37{ }^{\circ} \mathrm{C}$, and hydrolysis of the fluorogenic substrate was monitored via an i-TECAN Infinite M200 plate reader (excitation: $485 \mathrm{~nm}$; emission: 538 $\mathrm{nm}$ ). Readings were taken every $30 \mathrm{~min}$ for $6 \mathrm{~h}$. All compounds, including enopeptin A (25 $\mu \mathrm{M}$, positive control), ACP5 (50 $\mu \mathrm{M}$, positive control), and DMSO (1\%, negative control) were normalized relative to background FITC- $\beta$-casein fluorescence $(\triangle \mathrm{RFU}=$ sample dosed well fluorescence - DMSO dosed well fluorescence).

\section{Decapeptide Degradation Assay}

As described previously, ${ }^{38} 25 \mathrm{nM}$ tetradecameric EcClpP in buffer B (25 mM HEPES, pH $7.5,100 \mathrm{mM} \mathrm{KCl}, 5 \mathrm{mM} \mathrm{MgCl}_{2}, 10 \%$ glycerol, and $1 \mathrm{mM} \mathrm{DTT}$ ) was incubated with the compound of interest over a range of concentrations at $30{ }^{\circ} \mathrm{C}$ for $15 \mathrm{~min}$ in flat bottom, nonbinding, nonsterile, white polystyrene 96- well plates (Corning 3990). After the preincubation period $1 \mu \mathrm{L}$ of a $1.5 \mathrm{mM}$ Abz-DFAPKMALVPYNO2 (Biomatik) solution was added to each assay well to give a final assay concentration of $15 \mu \mathrm{M}$ fluorogenic decapeptide and final assay volume of $100 \mu \mathrm{L}$. Assay plates were incubated at $30^{\circ} \mathrm{C}$, and hydrolysis of the fluorogenic peptide was monitored via an i-TECAN Infinite M200 plate reader (excitation: $320 \mathrm{~nm}$; emission: $420 \mathrm{~nm}$ ). Readings were taken every $30 \mathrm{~min}$ for $2 \mathrm{~h}$. All compounds, including ADEP1 (positive control) and DMSO (1\%, negative control), were normalized relative to background Abz-DFAPKMALVPY ${ }^{\mathrm{NO} 2}$ fluorescence $(\triangle \mathrm{RFU}=$ sample dosed well fluorescence - DMSO dosed well fluorescence).

\section{FITC-Casein Degradation Assay}

A $257 \mathrm{nM}$ tetradecameric $E c \mathrm{ClpP}$ in buffer A ( $25 \mathrm{mM}$ Tris- $\mathrm{HCl}, \mathrm{pH} 7.5$, and $100 \mathrm{mM} \mathrm{KCl})$ was incubated with the compound of interest over a range of concentrations at $37^{\circ} \mathrm{C}$ for 15 min in flat bottom, nonbinding, nonsterile, white polystyrene 96-well plates (Corning 3990). After the preincubation period $1 \mu \mathrm{L}$ of a $0.45 \mathrm{mM}$ FITC- $\beta$-casein solution in buffer A was added to each assay well to give a final assay concentration of $4.5 \mu \mathrm{M}$ FITC- $\beta$-casein and final assay volume of $100 \mu \mathrm{L}$. Assay plates were incubated at $37^{\circ} \mathrm{C}$, and hydrolysis of the fluorogenic substrate was monitored via an i-TECAN Infinite M200 plate reader (excitation: $485 \mathrm{~nm}$; emission: $538 \mathrm{~nm}$ ). Readings were taken every $30 \mathrm{~min}$ for $6 \mathrm{~h}$. All compounds, including ADEP1 (positive control) and DMSO (1\%, negative control), were normalized relative to background FITC- $\beta$-casein fluorescence $(\triangle \mathrm{RFU}=$ sample dosed well fluorescence - DMSO dosed well fluorescence).

\section{SDS-PAGE Analysis}

A $420 \mathrm{nM}$ tetradecameric $E c \mathrm{ClpP}$ or $B s \mathrm{ClpP}$ in buffer A $(59 \mu \mathrm{L})$ was incubated with the compound of interest at the desired concentration for $15 \mathrm{~min}$ at $37^{\circ} \mathrm{C}$ in Eppendorf tubes. A $16 \mu \mathrm{L}$ amount of a $1 \mathrm{mg} / \mathrm{mL}$ bovine $\beta$-casein (Sigma-Aldrich C6905, Bio-Ultra $298 \%$ ) solution in buffer A was then added for a final substrate concentration of $7.5 \mu \mathrm{M}$ and a final assay volume of $75 \mu \mathrm{L}$. The reaction was quenched with $25 \mu \mathrm{L}$ of Laemmli loading buffer (Alfa Aesar J60015) at $80^{\circ} \mathrm{C}$. Individual reactions were quenched after $5 \mathrm{~min}, 30 \mathrm{~min}, 1 \mathrm{~h}$, and/or $2 \mathrm{~h}$ depending on the compound. The samples were then boiled for approximately 1 
min prior to loading. Time-dependent degradation of the $\beta$-casein band was visualized using SDS-Page on a $10 \%$ acrylamide Bis-Tris gel.

\section{MIC Determination}

Using the 2-fold dilution technique in 96-well microtiter plates, cells were subcultured (1:100 dilution) in fresh LB media (tryptone $10 \mathrm{~g} / \mathrm{L}$, yeast extract $5 \mathrm{~g} / \mathrm{L}$, and $\mathrm{NaCl} 5 \mathrm{~g} / \mathrm{L}$ ) and grown to an $\mathrm{OD}_{600}$ of $\sim 1.0$. Cells were inoculated at a density of $10^{5}$ cells per $\mathrm{mL}$ into LB media in the presence of 2 -fold increasing concentrations of $\mathbf{1}$. MIC values were determined visually after incubation of the microtiter plates at $37^{\circ} \mathrm{C}$ for $18 \mathrm{~h}$.

\section{Supplementary Material}

Refer to Web version on PubMed Central for supplementary material.

\section{Acknowledgments}

This work was supported by the University of Oklahoma Junior Faculty Fellowship (A.S.D.), Oklahoma Center for the Advancement of Science and Technology (OCAST, HR15-161), and University of Oklahoma start-up funding. The initial screen was partially subsidized by an Undergraduate Research Opportunity Program (UROP) Award (J.A.C.). Research reported in this publication was supported by an Institutional Development Award (IDeA) from the National Institute of General Medical Sciences of the National Institutes of Health under grant number P20GM103640. In addition, we thank Prof. R. Sauer and Dr. K. Schmitz (MIT) for the EcClpP and BsClpP plasmids, Prof. R. Cichewicz (OU) and his research team for access to the natural product library, and Prof. $\mathrm{H}$. Zgurskaya $(\mathrm{OU})$ and her research team for preliminary microbiology work.

\section{REFERENCES}

1. Antibiotic Resistance Threats in the United States, 2013. Center for Disease Control and Prevention; 2013.

2. Fischbach MA, Walsh CT. Science. 2009; 325:1089-1093. [PubMed: 19713519]

3. Wright GD. BMC Biol. 2010; 8:123-128. [PubMed: 20887638]

4. Walsh CT, Wencewicz TA. J. Antibiot. 2014; 67:7-22. [PubMed: 23756684]

5. Lewis, K. Multidrug Tolerance of Biofilms and Persister Cells. In: Romeo, T., editor. Bacterial Biofilms. Springer; 2008. p. 107-131.

6. Gottesman S, Clark WP, Maurizi MR. J. Biol. Chem. 1990; 265:7886-7893. [PubMed: 2186030]

7. Hwang BJ, Woo KM, Goldberg AL, Chung CH. J. Biol. Chem. 1988; 263:8727-8734. [PubMed: 2967816]

8. Katayama Y, Gottesman S, Pumphrey J, Rudikoff S, Clark WP, Maurizi MR. J. Biol. Chem. 1988; 263:15226-15236. [PubMed: 3049606]

9. Katayama-Fujimura Y, Gottesman S, Maurizi MR. J. Biol. Chem. 1987; 262:4477-4485. [PubMed: 3549708]

10. Maurizi MR, Clark WP, Katayama Y, Rudikoff S, Pumphrey J, Bowers B, Gottesman S. J. Biol. Chem. 1990; 265:12536-12545. [PubMed: 2197275]

11. Maurizi, MR.; Thompson, MW.; Singh, SK.; Kim, SH. Methods in Enzymology. Vol. 244. Philadelphia, PA: Elsevier; 1994. Endopeptidase Clp: ATP-Dependent Clp Protease from Escherichia coli. p 314.10.1016/0076-6879(94)44025-5

12. Wang J, Hartling JA, Flanagan JM. Cell. 1997; 91:447-456. [PubMed: 9390554]

13. Gottesman S, Wickner S, Maurizi MR. Genes Dev. 1997; 11:815-823. [PubMed: 9106654]

14. Kruger E, Witt E, Ohlmeier S, Hanschke R, Hecker M. J. Bacteriol. 2000; 182:3259-3265. [PubMed: 10809708]

15. Raju RM, Goldberg AL, Rubin EJ. Nat. Rev. Drug Discovery. 2012; 11:777-789. [PubMed: 23023677] 
16. Yu AY, Houry WA. FEBS Lett. 2007; 581:3749-3757. [PubMed: 17499722]

17. Joshi SA, Hersch GL, Baker TA, Sauer RT. Nat. Struct. Mol. Biol. 2004; 11:404-411. [PubMed: 15064753]

18. Kim YI, Levchenko I, Fraczkowska K, Woodruff RV, Sauer RT, Baker TA. Nat. Struct. Biol. 2001; 8:230-233. [PubMed: 11224567]

19. Martin A, Baker TA, Sauer RT. Mol. Cell. 2007; 27:41-52. [PubMed: 17612489]

20. Thompson M, Satyendra SK, Maurizi MR. J. Biol. Chem. 1994; 269:18209-18215. [PubMed: 8027082]

21. Thompson MW, Maurizi MR. J. Biol. Chem. 1994; 269:18201-18208. [PubMed: 8027081]

22. Wickner S, Gottesman S, Skowyra D, Hoskins J, McKenney K, Maurizi MR. Proc. Natl. Acad. Sci. U. S. A. 1994; 91:12218-12222. [PubMed: 7991609]

23. Cordova JC, Olivares AO, Shin Y, Stinson BM, Calmat S, Schmitz KR, Aubin-Tam ME, Baker TA, Lang MJ, Sauer RT. Cell. 2014; 158:647-658. [PubMed: 25083874]

24. Lee ME, Baker TA, Sauer RT. J. Mol. Biol. 2010; 399:707-718. [PubMed: 20416323]

25. Carney DW, Schmitz KR, Truong JV, Sauer RT, Sello JK. J. Am. Chem. Soc. 2014; 136:19221929. [PubMed: 24422534]

26. Singh SK, Grimaud R, Hoskins JR, Wickner S, Maurizi MR. Proc. Natl. Acad. Sci. U. S. A. 2000; 97:8898-8903. [PubMed: 10922052]

27. Brotz-Oesterhelt H, Beyer D, Kroll HP, Endermann R, Ladel C, Schroeder W, Hinzen B, Raddatz S, Paulsen H, Henninger K, Bandow JE, Sahl HG, Labischinski H. Nat. Med. 2005; 11:10821087. [PubMed: 16200071]

28. Kirstein J, Hoffmann A, Lilie H, Schmidt R, Rubsamen-Waigmann H, Brotz-Oesterhelt H, Mogk A, Turgay K. EMBO Mol. Med. 2009; 1:37-49. [PubMed: 20049702]

29. Lee BG, Park EY, Lee KE, Jeon H, Sung KH, Paulsen H, Rubsamen-Schaeff H, Brotz-Oesterhelt H, Song HK. Nat. Struct. Mol. Biol. 2010; 17:471-478. [PubMed: 20305655]

30. Conlon BP, Nakayasu ES, Fleck LE, LaFleur MD, Isabella VM, Coleman K, Leonard SN, Smith RD, Adkins JN, Lewis K. Nature. 2013; 503:365-370. [PubMed: 24226776]

31. Lewis, K.; Conlon, B.; Nelson, ML.; Polastri, MP.; Dahl, TA. WO 2012/135846 A1. 2012 Oct 4.

32. Michael, KH.; Kastner, RE. U.S. Patent. 4,492,650. 1985 Jan 8.

33. Osada H, Yano T, Koshino H, Isono K. J. Antibiot. 1991; 44:1463-1466. [PubMed: 1778798]

34. Gersch M, Famulla K, Dahmen M, Gobl C, Malik I, Richter K, Korotkov VS, Sass P, RubsamenSchaeff H, Madl T, Brotz-Oesterhelt H, Sieber SA. Nat. Commun. 2015; 6:6320. [PubMed: 25695750]

35. Hinzen B, Raddatz S, Paulsen H, Lampe T, Schumacher A, Habich D, Hellwig V, Benet-Buchholz J, Endermann R, Labischinski H, Brotz-Oesterhelt H. ChemMedChem. 2006; 1:689-693. [PubMed: 16902918]

36. Socha AM, Tan NY, LaPlante KL, Sello JK. Bioorg. Med. Chem. 2010; 18:7193-7202. [PubMed: 20833054]

37. Lee, RE.; Zhao, Y.; Griffith, E.; Zheng, Z.; Singh, A. WO 2015/031871 A1. 2015 Mar 5.

38. Carney DW, Compton CL, Schmitz KR, Stevens JP, Sauer RT, Sello JK. ChemBioChem. 2014; 15:2216-2220. [PubMed: 25212124]

39. Compton CL, Carney DW, Groomes PV, Sello JK. ACS Infect. Dis. 2015; 1:53-58.

40. Houry, WA.; Leung, E.; Batey, RA.; Cossette, M.; Goodreid, J.; Datti, A.; Liu, J.; Nhieu, AJ.; Gray-Owen, SD.; Fai, EF.; Eger, BT. WO 2012/079164 A1. 2012 Jun 21.

41. Leung E, Datti A, Cossette M, Goodreid J, McCaw SE, Mah M, Nakhamchik A, Ogata K, El Bakkouri M, Cheng YQ, Wodak SJ, Eger BT, Pai EF, Liu J, Gray-Owen S, Batey RA, Houry WA. Chem. Biol. 2011; 18:1167-1178. [PubMed: 21944755]

42. Du L, Robles AJ, King JB, Powell DR, Miller AN, Mooberry SL, Cichewicz RH. Angew. Chem., Int. Ed. 2014; 53:804-809.

43. Niu G, Wang B, Zhang G, King JB, Cichewicz RH, Li J. Sci. Rep. 2015; 5:14694-14711. [PubMed: 26437882] 
44. Wang B, You J, King JB, Cai S, Park E, Powell DR, Cichewicz RH. J. Nat. Prod. 2014; 77 227310.1021/np500531j.

45. Du L, Risinger AL, King JB, Powell DR, Cichewicz RH. J. Nat. Prod. 2014; 77:1753-1757. [PubMed: 24999749]

46. Du L, Robles AJ, King JB, Mooberry SL, Cichewicz RH. J. Nat. Prod. 2014; 77:1459-1466. [PubMed: 24893224]

47. Koshino H, Osada H, Yano T, Uzawa J, Isono K. Tetrahedron Lett. 1991; 32:7707-7710.

48. Brideau C, Gunter B, Pikounis B, Liaw A. J. Biomol. Screening. 2003; 8:634-647.

49. Pelz O, Gilsdorf M, Boutros M. BMC Bioinf. 2010; 11 18510.1186/1471-2105-11-185.

50. Whyte AC, Gloer JB. J. Nat. Prod. 1996; 59:1093-1095. [PubMed: 8946752]

51. Finefield JM, Kato H, Greshock TJ, Sherman DH, Tsukamoto S, Williams RM. Org. Lett. 2011; 13:3802-3805. [PubMed: 21714564]

52. Mercado-Marin EV, Garcia-Reynaga P, Romminger S, Pimenta EF, Romney DK, Lodewyk MW, Williams DE, Andersen RJ, Miller SJ, Tantillo DJ, Berlinck RG, Sarpong R. Nature. 2014; 509:318-324. [PubMed: 24828190]

53. Finefield JM, Frisvad JC, Sherman DH, Williams RM. J. Nat. Prod. 2012; 75:812-833. [PubMed: 22502590]

54. Peng J, Zhang XY, Tu ZC, Xu XY, Qi SH. J. Nat. Prod. 2013; 76:983-987. [PubMed: 23701598]

55. Kato H, Yoshida T, Tokue T, Nojiri Y, Hirota H, Ohta T, Williams RM, Tsukamoto S. Angew. Chem., Int. Ed. 2007; 46:2254-2256.

56. Rosner JL, Martin RG. J. Bacteriol. 2013; 195:1042-1050. [PubMed: 23264577]

57. Mima T, Joshi S, Gomez-Escalada M, Schweizer HP. J. Bacteriol. 2007; 189:7600-7609. [PubMed: 17720796]

58. Flanagan JM, Wall JS, Capel MS, Schneider DK, Shanklin J. Biochemistry. 1995; 34:1091010917. [PubMed: 7662672]

59. Gill SC, von Hippel PH. Anal. Biochem. 1989; 182:319-326. [PubMed: 2610349] 


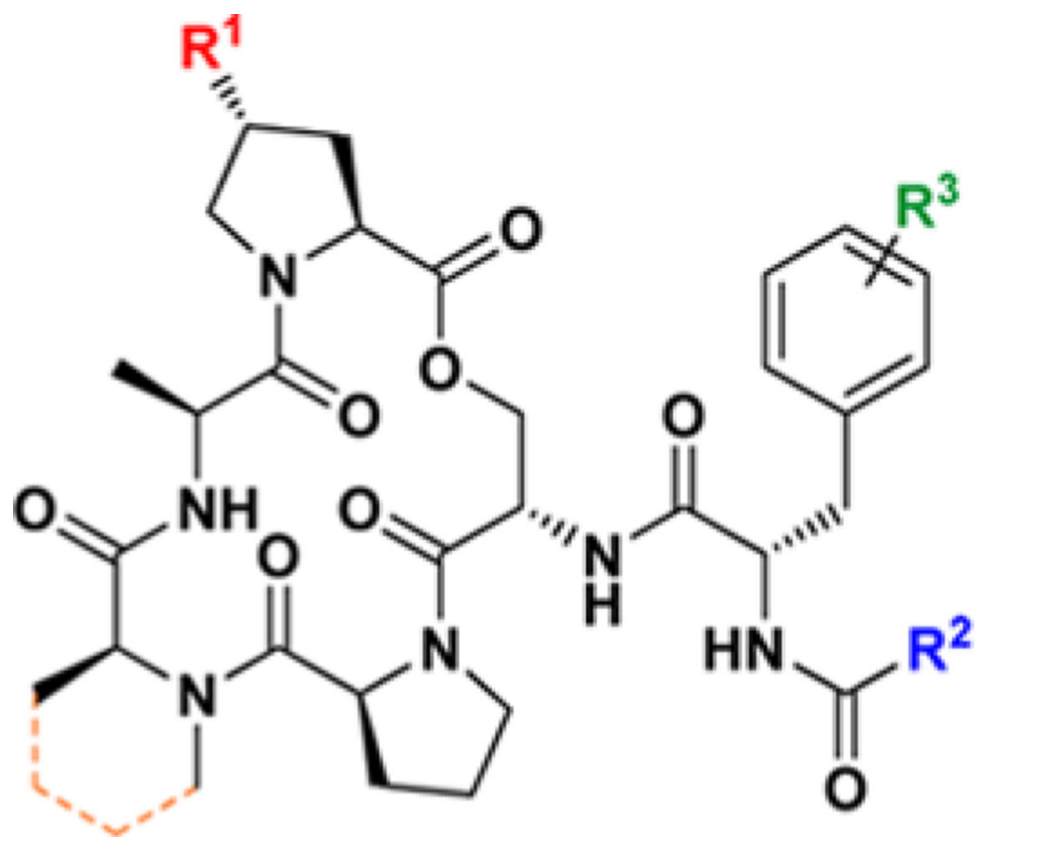

\section{Examples:}

$\mathbf{R}^{1}=\mathrm{H}$ or $\mathrm{CH}_{3}$

$\mathbf{R}^{2}=$ aliphatic chain

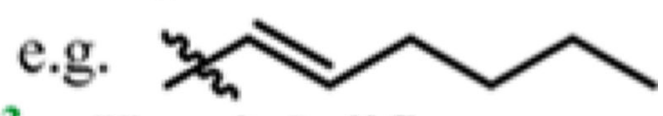
$\mathrm{R}^{3}=\mathrm{H}$ or 3,5 -difluoro

Figure 1.

General structure of peptide-based ADEP antibiotics. 


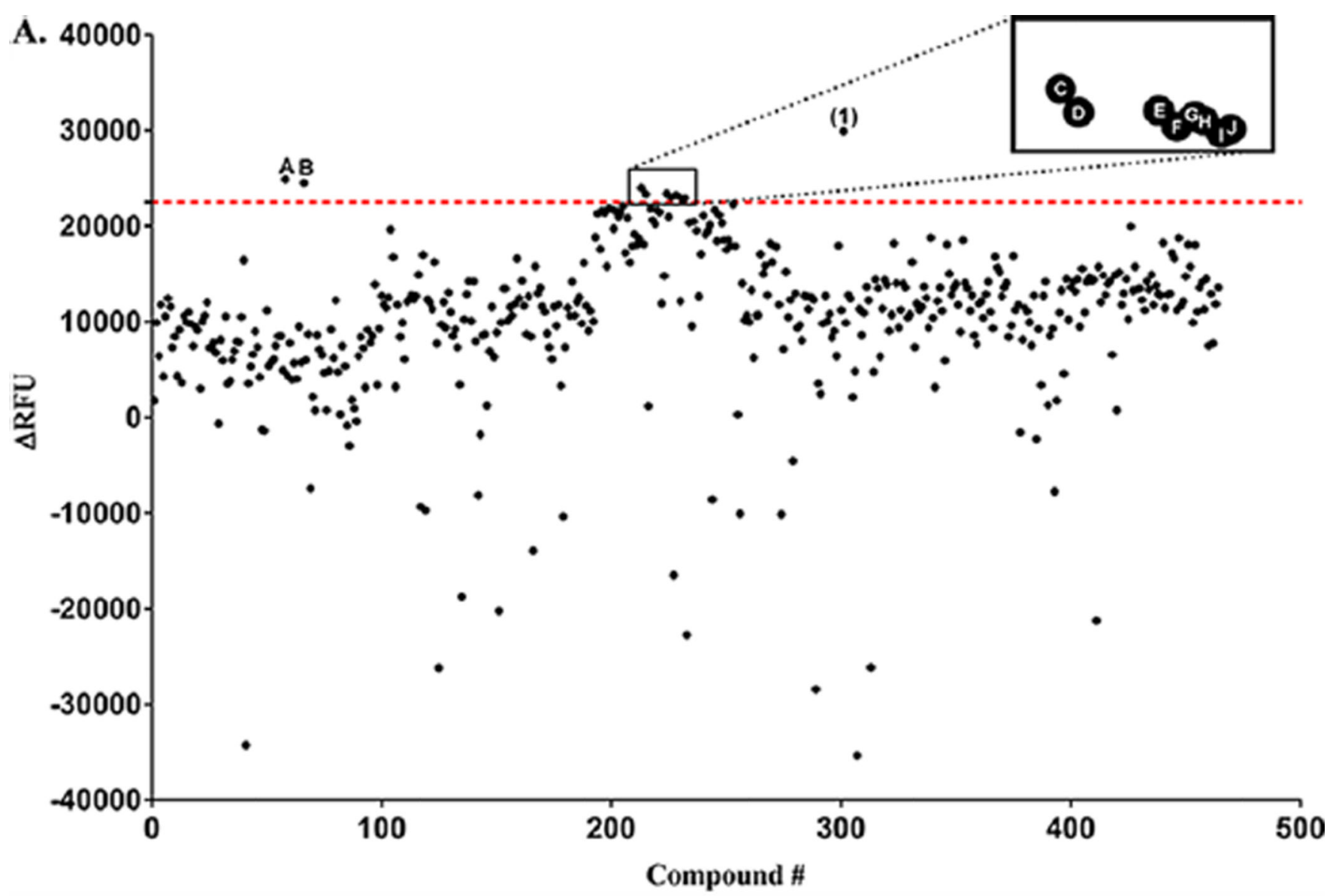

B.

\begin{tabular}{cccccc} 
"Hit" & SRFU & IF & PA \\
\hline $\mathrm{C}$ & 23997 & yes & $\mathrm{ND}$ \\
$\mathrm{D}$ & 23372 & yes & $\mathrm{ND}$ \\
$\mathrm{E}$ & 23404 & yes & $\mathrm{ND}$ \\
$\mathrm{F}$ & 22978 & yes & $\mathrm{ND}$ \\
$\mathrm{G}$ & 23214 & yes & $\mathrm{ND}$ \\
$\mathrm{H}$ & 23122 & yes & $\mathrm{ND}$ \\
$\mathrm{I}$ & 22798 & yes & $\mathrm{ND}$ \\
$\mathrm{J}$ & 22904 & yes & $\mathrm{ND}$ \\
$\mathbf{1}$ & 29909 & no & no
\end{tabular}

Figure 2.

(A) Raw FITC- $\beta$-casein degradation screening results. Threshold for analysis is indicated by the red line ( $\triangle \mathrm{RFU} \geq 22500$ ). Inset: Enlarged area of threshold exceeding "hits". (B) Fluorescence data, validation of initial "hits", and structure of sclerotiamide (1). $\Delta$ RFU = change in relative fluorescence units, IF = intrinsic compound fluorescence, $\mathrm{PA}=$ inherent compound proteolytic activity, $\mathrm{ND}=$ not determined. 

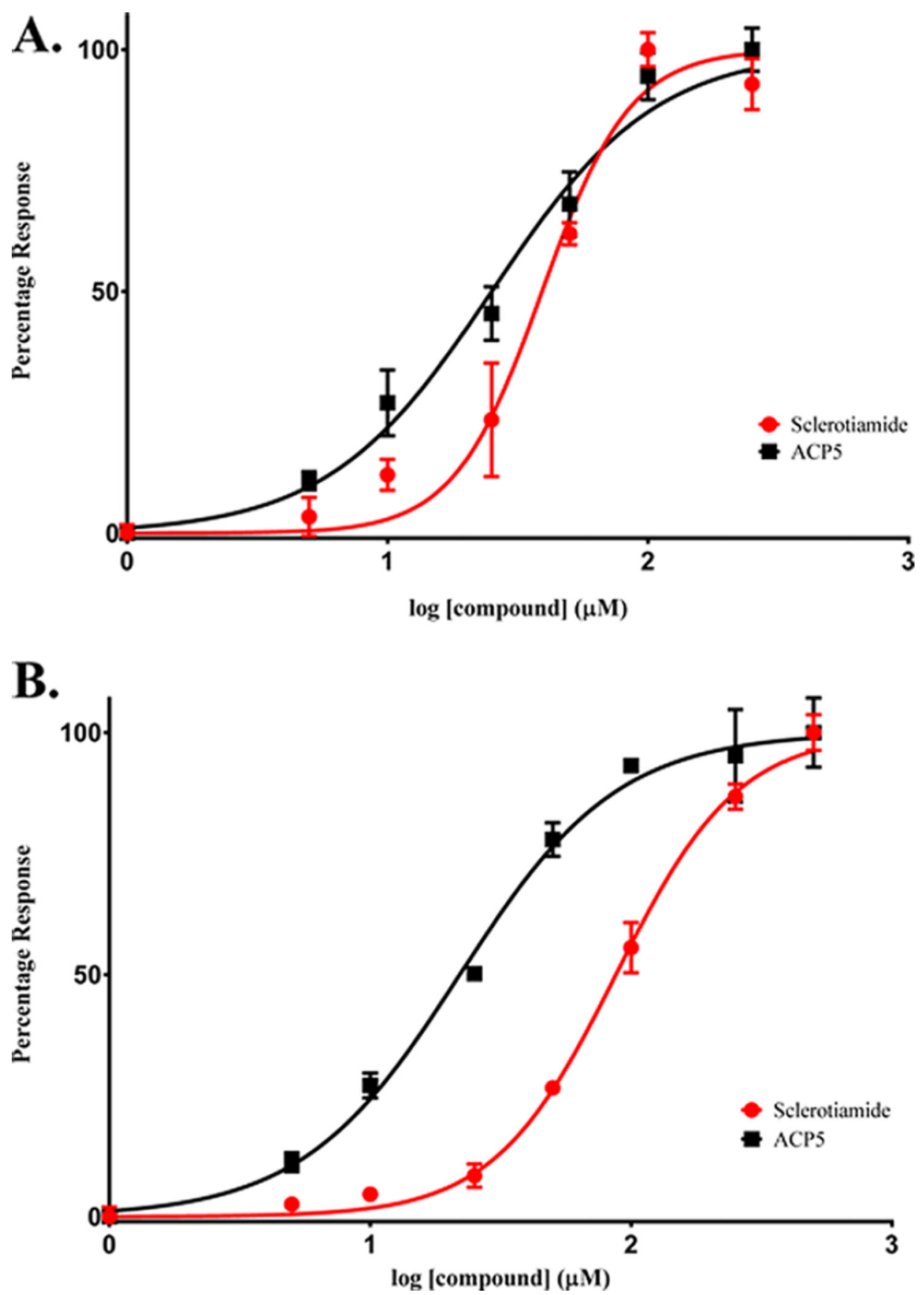

Figure 3.

Dose-dependent $E c C l p P$ activation by ACP5 and 1. (A) Substrate $=$ AbzDFAPKMALVPY ${ }^{\mathrm{NO} 2}$. (B) Substrate = FITC- $\beta$-casein. 


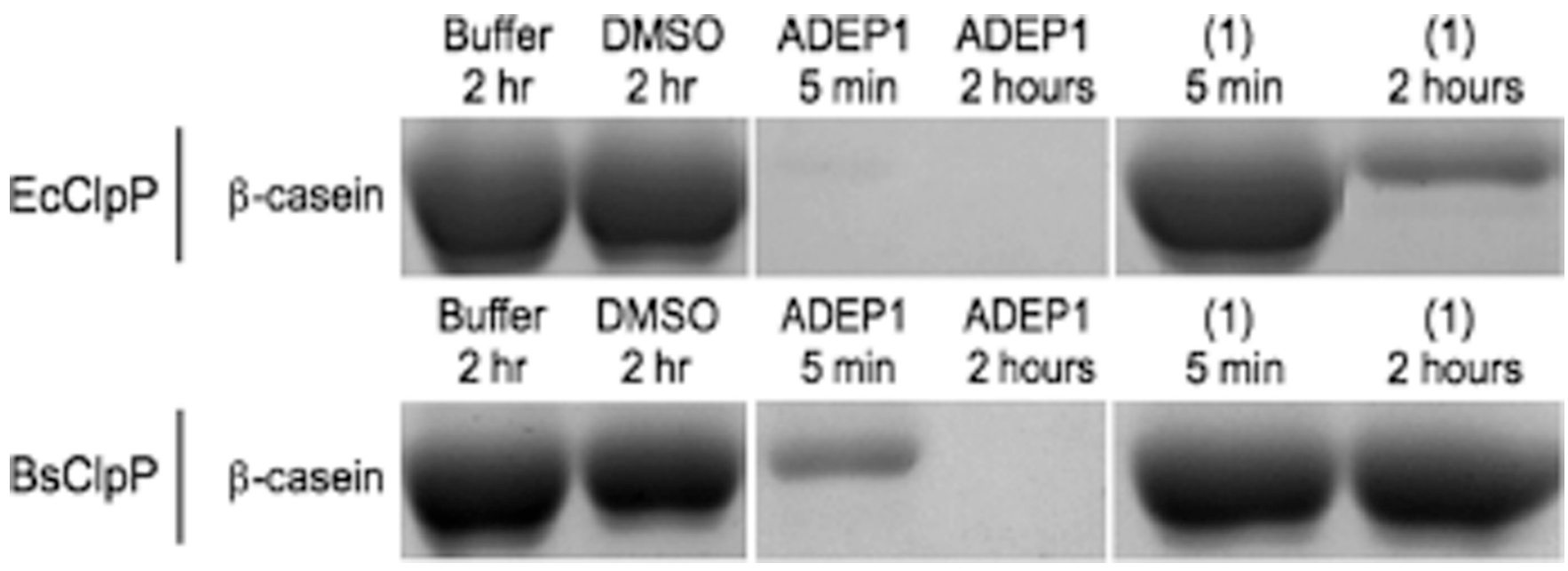

Figure 4.

SDS-PAGE analysis of ClpP homologue-dependent degradation of unlabeled $\beta$-casein by 1 $(50 \mu \mathrm{M})$ in comparison to ADEP1 $(1 \mu \mathrm{M})$. 
A.

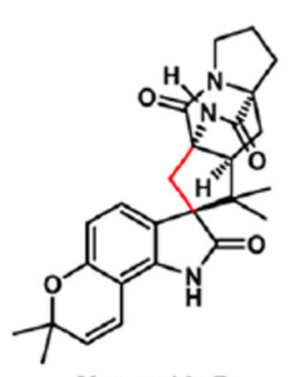

Notoamide B 2

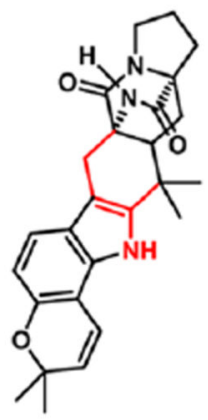

Stephacidin A

5

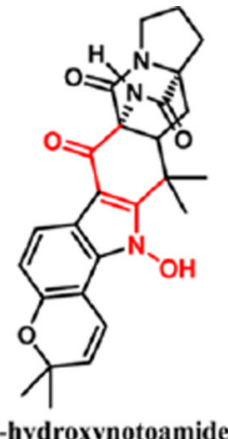

3
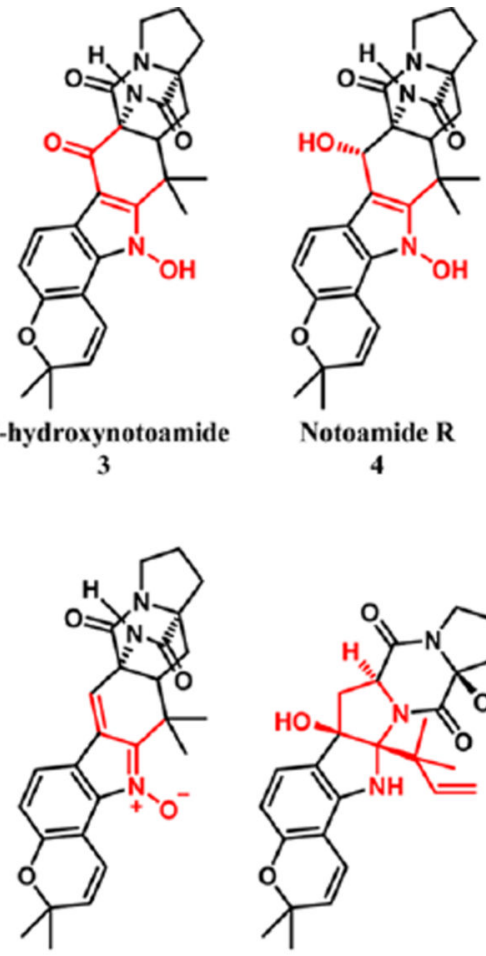

CJ17665

6

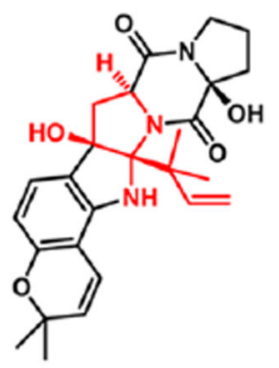

Norgenamide D

7

B.

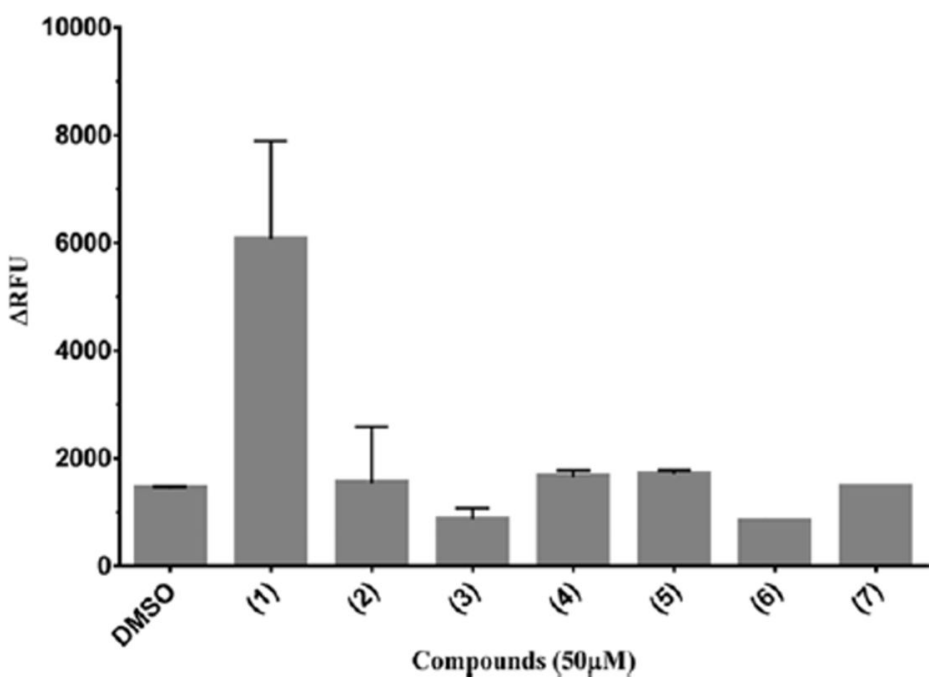

Figure 5.

(A) Structures of paraherquamide-related compounds present in the initial FITC- $\beta$-casein degradation screen. (B) Relative EcClpP activation of $\mathbf{1}$ and related compounds. Substrate = Abz-DFAPKMALVPYNO2. 


\section{Table 1}

Dose-Response Comparison of ADEP1, ACP5, and 1 for the Decapeptide (DFAPKMALVPYNO2) and Unstructured Protein (FITC- $\beta$-casein) Substrates

\begin{tabular}{lcrc}
\hline & \multicolumn{3}{c}{$\mathbf{E C}_{\mathbf{5 0}}(\boldsymbol{\mu M})$} \\
\cline { 2 - 4 } compound & DFAP & FITC-casein & Hill slope \\
\hline ADEP1 & $0.1 \pm 0.02$ & $1.2 \pm 0.1$ & $1.6 / 1.5$ \\
ACP5 & $25.4 \pm 3.6$ & $22.2 \pm 2.3$ & $1.4 / 1.4$ \\
$\mathbf{1}$ & $39.6 \pm 4.9$ & $87.5 \pm 5.0$ & $2.6 / 1.9$ \\
\hline
\end{tabular}

